\title{
Development of lymphocyte subpopulations in local breed chickens
}

\author{
Adil Sabr Al-Ogaili'i ${ }^{10}$ and Samer Sadeq Hameed² \\ 1. Department of Medical Laboratory Techniques, Kut Technical Institute, Middle Technical University, Baghdad, Iraq; 2. \\ Department of Pathology and Poultry Diseases, College of Veterinary Medicine, University of Baghdad, Baghdad, Iraq. \\ Corresponding author: Adil Sabr Al-Ogaili, e-mail: akarsabradil@gmail.com \\ Co-author: SSH: samer.hameed@covm.uobaghdad.edu.iq \\ Received: 09-03-2021, Accepted: 01-06-2021, Published online: 19-07-2021
}

doi: www.doi.org/10.14202/vetworld.2021.1846-1852 How to cite this article: Al-Ogaili AS, Hameed SS (2021)

Development of lymphocyte subpopulations in local breed chickens, Veterinary World, 14(7): 1846-1852.

\begin{abstract}
Background and Aim: Local breeds of chicken are known to have relatively higher disease resistance to many endemic diseases and diseases that are highly virulent in commercial chickens. This study aimed to address the lymphocyte subpopulations in three constitutive immune system organs (thymus, bursa of Fabricius, and spleen) in 30, 8-week-old, male local breed chickens.
\end{abstract}

\begin{abstract}
Materials and Methods: The $\mathrm{T}\left(\mathrm{CD}^{+}\right)$and $\mathrm{B}$ lymphocytes $\left(\mathrm{Bu}-1^{+}\right)$were identified through one-color, direct immunofluorescent staining of the thymus, bursa, and spleen lymphocytes. Likewise, two-color, direct immunofluorescent staining was performed to identify the CD4- and/or CD8-defined T lymphocytes. The proportions of T and B lymphocytes and CD4- and/or CD8 defined chicken lymphocyte subsets in lymphoid suspensions prepared from the thymus, bursa, and spleen were determined by flow cytometry.
\end{abstract}

Results: $\mathrm{CD}^{+}$cells, particularly those positive for $\mathrm{CD}^{+}{ }^{+} \mathrm{CD} 8^{-}$, were dominant in the thymus, whereas cells expressing the $\mathrm{Bu}-1$ marker were predominant in the bursa of Fabricius. The proportion of $\mathrm{T}$ and $\mathrm{B}$ cells was almost equal in the spleen, with more cells expressing the $\mathrm{CD} 4{ }^{-} \mathrm{CD} 8^{+}$marker in the red pulp.

Conclusion: These findings indicate that local breeds of chicken could serve as a reliable model for studying the immune system of commercial light chicken breeds, due to the similarity in the presence and the distribution of the immune cells.

Keywords: direct immunofluorescent staining, flow cytometry, local breed chickens, lymphocytes subpopulations.

\section{Introduction}

Lymphocytes are responsible for acquired immune responses in higher vertebrates. As in other vertebrates, the lymphocytes in chickens are divided into $\mathrm{B}$ and $\mathrm{T}$ lymphocytes, depending on their origin and function $[1,2]$. Both cell lineages are further subdivided into distinct subpopulations depending on the presence of specific markers on the cell surface [3]. However, the traditional methods for the examination and differentiation of these cells are not sufficient to recognize the major and minor subpopulations. At present, molecular-based methods appear to be most accurate to distinguish between the cell types [4]. In chickens and many domesticated avian species, Bu-1 is a constant B lymphocyte marker (in pre-plasma B cells) before maturation $[5,6]$. On the other hand, T lymphocytes express $\mathrm{CD}^{+}$complexes (T cell receptor). Subsets of $\mathrm{T}$ lymphocytes express additional surface markers such as CD4, a common marker of T helper lymphocytes $\left(\mathrm{T}_{\mathrm{H}}\right)$, whereas CD8 is the common surface marker of cytotoxic T lymphocytes [7,8]. In the thymus, the precursor thymocyte population

Copyright: Al-Ogaili and Hameed. Open Access. This article is distributed under the terms of the Creative Commons Attribution 4.0 International License (http://creativecommons.org/licenses/ by/4.0/), which permits unrestricted use, distribution, and reproduction in any medium, provided you give appropriate credit to the original author(s) and the source, provide a link to the Creative Commons license, and indicate if changes were made. The Creative Commons Public Domain Dedication waiver (http:// creativecommons.org/publicdomain/zero/1.0/) applies to the data made available in this article, unless otherwise stated. expresses $\mathrm{CD}^{-} \mathrm{CD}^{-}$, which later develops into $\mathrm{CD}^{+} \mathrm{CD}^{-}$or $\mathrm{CD} 4^{-} \mathrm{CD}^{+} \mathrm{T}$ lymphocytes. These single positive $\mathrm{T}$ lymphocytes respond specifically to certain antigens. The $\mathrm{CD} 4^{+} \mathrm{CD} 8^{-}$cell, better known as CD4 cell, is responsible for inducing an immune response against exogenous antigens. On the other hand, the $\mathrm{CD}^{-} \mathrm{CD}^{+}$cell, also known as $\mathrm{CD} 8$ cell, is responsible for orchestrating an immune response against exogenous antigens $[9,10]$. Tag-labeled specific monoclonal antibodies are used to distinguish these cell markers [11].

Local breeds of chickens are more refractory to many highly pathogenic diseases that cause serious outbreaks among commercial poultry [12]. Yet, published reports on the development of a lymphocyte subpopulation in these breeds are scarce.

In this study, we sought to determine the presence of any shift in the density and distribution of professional immune cells in a local breed of male chickens at the molecular level. The presence and density of $\mathrm{T}$ and $\mathrm{B}$ lymphocytes in 8-week-old local breed male chickens were examined by determining the specific surface markers through immunohistochemistry and flow cytometry.

\section{Materials and Methods}

\section{Ethical approval}

The study and all tests and procedures were approved by the Scientific and Animal Care Committee, Department of Pathology and Poultry 
Disease, College of Veterinary Medicine, University of Baghdad.

\section{Study period and location}

This study was conducted from March to June 2020. Fertile eggs hatchery were kept in and the hatched birds were raised in the premises of Kut-Tech Institute, Middle Technical University, Kut, Wasit, Iraq.

\section{Chickens}

Thirty, 8-week-old male local breed chickens were used. Only male chickens were selected to exclude the effect of sex on the immunity of these birds. The breeding process was started by incubating the eggs from local breeds in a hatchery using the 1-day sex protocol. The birds were raised under sterile conditions with water and feed ad libitum; no vaccines or antibiotics were used. At the age of 8 weeks, the birds were euthanized and the immune system organs were collected under sterile conditions.

\section{Weights and weight percentages of the birds and their primary and secondary lymphoid organs}

The chickens were euthanized and weighed. The primary lymphoid organs (thymus and bursae) and spleens were dissected and weighed. The average of the total weights of the lymphoid organs and their percentages in relation to the average of the total bodyweight were calculated as previously described [13].

\section{Preparation of single cell suspension from the spleen, thymus, and bursa of Fabricius}

The splenocytes were separated by density gradient centrifugation using the Ficoll-Paque method (Fico/Lite LymphoH ${ }^{\mathrm{TM}}$, Atlanta Biologicals, USA; density 1.077). Slices of the spleen (about 0.2$0.25 \mathrm{~g} / \mathrm{organ} / \mathrm{bird})$ stored in icy $1 \times$ phosphate-buffered saline ( $1 \times \mathrm{PBS} ; \mathrm{pH} 7.4)$. These slices were passed through a nylon mesh (pore size, $60 \mu \mathrm{m}$; Tetko, Elmsford, NY) and were collected in a sterile beaker This was followed by the immediate addition of cold $1 \times \mathrm{PBS}$ to cover the tissue pieces. The contents of the beaker were transferred to a sterile, screw-capped tube. The splenocyte suspension was washed by spinning at $250 \times \mathrm{g}$, at $4^{\circ} \mathrm{C}$ for $8 \mathrm{~min}$. The supernatant fluid was discarded, and the pellet was re-suspended in $5 \mathrm{~mL}$ of $1 \times \mathrm{PBS}$ at room temperature (RT). Next, $5 \mathrm{~mL}$ of the spleen cell suspension was carefully layered over $5 \mathrm{~mL}$ of the Ficoll 1077 at RT. The mixture was centrifuged at RT, $400 \times g$ for $30 \mathrm{~min}$. After centrifugation, the cells at the PBS/Ficoll interface were aspirated using a Pasteur pipette and placed into a tube containing $8 \mathrm{~mL}$ of cold $1 \times$ PBS [14-16]. The splenocytes were washed $3 \times$ by centrifugation at $250 \times g$ and $4^{\circ} \mathrm{C}$, for $8 \mathrm{~min}$. The pellet formed was re-suspended in $2 \mathrm{~mL}$ of cold $1 \times \mathrm{PBS}$ and placed on ice.

The $1 \times \mathrm{PBS}$ was treated with $0.1 \%$ sodium azide to prevent the cells from internalizing the markers and labels; $1 \%$ bovine serum albumin was used to block and prevents the non-specific binding of the antibodies [14].
As with the spleens, the bursae and thymi were dissected and weighed. One thymic lobe and a piece of bursa of Fabricius were collected from each bird ( $\sim 0.2 \mathrm{~g} /$ organ $/$ bird). The samples were cut into pieces and stored in $1 \times$ PBS on ice. The tissue pieces were forced through a nylon mesh as described earlier. Cold $1 \times$ PBS was immediately added until the tissue pieces were covered by the solution. However, the thymocyte cell suspension has a high fat content; therefore, fat was completely removed from the suspension after the third wash (by centrifugation as described for the splenocytes). The pellet was re-suspended in $5 \mathrm{~mL}$ of cold $1 \times$ PBS. After washing the cells again, the supernatant was discarded, and the pellet was re-suspended in $5 \mathrm{~mL}$ of ice-cold $1 \times \mathrm{PBS}$ [17-19].

\section{Determination of the cell concentrations}

The concentrations of the splenocytes, thymocytes, and bursa cells were determined using a hemocytometer (stage-objective, $40 \times$ ). Then, $20 \mu \mathrm{L}$ of the cell suspension was added to $180 \mu \mathrm{L}$ of Trypan bluePBS $(0.04 \% \mathrm{w} / \mathrm{v}$ in $1 \times \mathrm{PBS})$ in a microcentrifuge tube and mixed well. The stain penetrates dead cells and stains the proteins blue. The cells were diluted with $1 \times$ PBS until a final concentration of $4 \times 10^{7}$ cell $/ \mathrm{mL}$ was reached [20].

\section{Immunohistochemistry}

Frozen sections of spleen (thickness, $6 \mu \mathrm{m}$ ) were obtained using a cryostat (temperature, $-22^{\circ} \mathrm{C}$ ) (Thermo Fisher Scientific, USA). The sections were fixed in acetone for 5 min using poly-L lysine-coated slides (Sigma-Aldrich). Inside a humidifying chamber, the tissues were stored in PBS $/ 10 \%$ horse serum ([HS] to prevent non-specific staining) (Thermo Fisher Scientific) overnight at RT. After incubation and three washes with $1 \times \mathrm{PBS}, 80 \mu \mathrm{L}$ of a primary antibody/diluent was added and the sections were incubated for $30 \mathrm{~min}$ at RT. The sections were washed again and $80 \mu \mathrm{L}$ of biotinylated horse anti-mouse immunoglobulin (Ig) G was added as the secondary antibody (Thermo Fisher Scientific).

The sections were incubated for $30 \mathrm{~min}$ at RT followed by 5 washes with PBS. Then, $80 \mu \mathrm{L}$ of avidin-biotin complex reagent was immediately added and the sections were incubated for $30 \mathrm{~min}$ at RT. The sections were washed (5 times) and $100 \mu \mathrm{L}$ of "charged" DAB (3, 3'-diaminobenzidine) (Abcam, USA) was added to each slide for color development. After a final course of washing, methyl green was added to the sections, which were then incubated for $1 \mathrm{~h}$. The slides were dipped in tap water and passed through a series of dehydrating baths of ethanol as follows: $70 \%, 95 \%$, and $100 \%$ for $30 \mathrm{~s}, 100 \%$ ethanol-100\% Americlear (50:50 mix) for $15 \mathrm{~s}$, and 100\% Americlear for $1 \min [21,22]$.

\section{Flow cytometry}

Cell suspensions from primary and secondary lymphoid organs, that is, thymus, bursa of Fabricius, and spleen, were subjected to flow 
cytometry procedure. For the one-color, direct immunofluorescent staining procedure, mouse anti-chicken CD3-fluorescein isothiocyanate (FITC)-conjugated monoclonal antibody (mouse IgG1) (Southern Biotech, Alabama, USA), and mouse anti-chicken $\mathrm{Bu}-1$-phycoerythrin (PE)-conjugated $\mathrm{mAb}$ (mouse IgG1) (Southern Biotech) were used to determine the percentages of $\mathrm{T}\left(\mathrm{CD}^{+}\right)$and $\mathrm{B}\left(\mathrm{Bu}-1^{+}\right)$cells in the three cell suspensions, respectively. Alternatively, mouse anti-chicken CD4-FITC-conjugated $\mathrm{mAb}$ (mouse IgG1) (Southern Biotech) and mouse antichicken CD8-PE-conjugated $\mathrm{mAb}$ (mouse IgG1) (Southern Biotech) were used in the two-color, direct immunofluorescent staining procedure to identify the $\mathrm{CD}^{+}$and/or $\mathrm{CD}^{+}$markers, respectively, on the $\mathrm{T}$ lymphocytes.

Fifty microliters of each cell suspension ( $210^{6}$ cells) were added to a 96-well round-bottom microtiter plate (four columns were used/organ). The first column was used as the isotype control with FITC- and PE-conjugated mouse IgG1 that does not express any chicken molecules specificity (Sigma). Fifty microliters each of mouse anti-chicken CD3FITC $\mathrm{mAb}$ and mouse anti-Bu-1-PE mAb were added to the second and third columns, respectively. A mixture $(50 \mu \mathrm{L})$ of mouse anti-CD4-FITC and mouse anti-chicken CD8-PE mAb (ratio 1:1) was added to the fourth column. The procedure was conducted as previously described $[3,4]$.

\section{Results}

\section{Weight and weight percentage of the organs}

The total bodyweights of the chickens and the weights of the primary and secondary lymphoid organs were measured. The average bodyweight was $1128 \mathrm{~g}$. The proportion of each lymphoid organ was calculated depending on the individual organ in relation to the total bodyweight (Table-1).

\section{Viable/dead cells in the primary and secondary lym- phoid organs}

The average percentages of viable and dead cells per gram of tissue and the percentages of viable and dead cells in relation to the weight of the whole organ are shown in Table- 2 .

\section{Immunohistochemistry}

\section{Thymus and bursa of Fabricius}

Sections from the thymus showed dense cell populations expressing both CD4 and CD8 markers (Figure-1c and d). On the other hand, the bursa of Fabricius cells demonstrated dense populations of lymphocytes, which expressed the Bu-1 marker (Figure-1b).

\section{Spleen}

Lymphocytes with $\mathrm{CD} 8\left(\mathrm{CD} 4^{-} \mathrm{CD} 8^{+}\right)$marker were dominant in the red bulb of the spleen (Figure-2b). Other lymphocytes expressing, the CD3 (Figure-2c) and $\mathrm{Bu}-1$ (Figure-2d) markers were detected over
Table-1: Measurement of the total weight and percentage of bodyweight of the thymus, bursa of Fabricius and spleen in 8-week old males local breed of chickens*.

\begin{tabular}{lccc}
\hline Measurement $^{+}$ & Thymus & Bursa & Spleen \\
\hline Weight $(\mathrm{g})$ & $4.107 \pm 0.292$ & $3.64 \pm 0.14$ & $2.48 \pm 0.206$ \\
$\%$ of BW & $0.213 \pm 0.009$ & $0.322 \pm 0.007$ & $0.131 \pm 0.012$ \\
\hline
\end{tabular}

Average of organ weights were calculated in grams and weight percentages. *Bodyweight-adjusted lymphoid organs weight. 'Data correspond to the arithmetic means \pm SE of the results $(n=30)$. 'The average bodyweight (BW/gm) 1128 \pm 46.2

Table-2: Number of viable cells per gram of tissue or per the whole organ.

\begin{tabular}{lccc}
\hline Measurement $^{*}$ & Thymus & Bursa & Spleen \\
\hline Cells/gram $^{\dagger}$ & $1.25 \times 10^{9}$ & $2.22 \times 10^{9}$ & $6.27 \times 10^{8}$ \\
Cells/organ $^{\dagger}$ & $4.59 \times 10^{9}$ & $3.89 \times 10^{9}$ & $1.53 \times 10^{9}$ \\
${\text { Average dead cells }(\%)^{+}}^{+}$ & 19 & 14.9 & 29.7 \\
\hline
\end{tabular}

The percentage of dead cells in thymus, bursa of Fabricius and spleen has been calculated in 8 week-old male local breed chickens, ${ }^{*}$ Cell suspension was prepared differently according to the organ evaluated. In case of spleen, density gradient centrifugation over Ficoll was performed. Thymocytes suspension did not require further purification steps. ${ }^{\dagger}$ Average was taken after two readings in two chambers of the hemocytometer

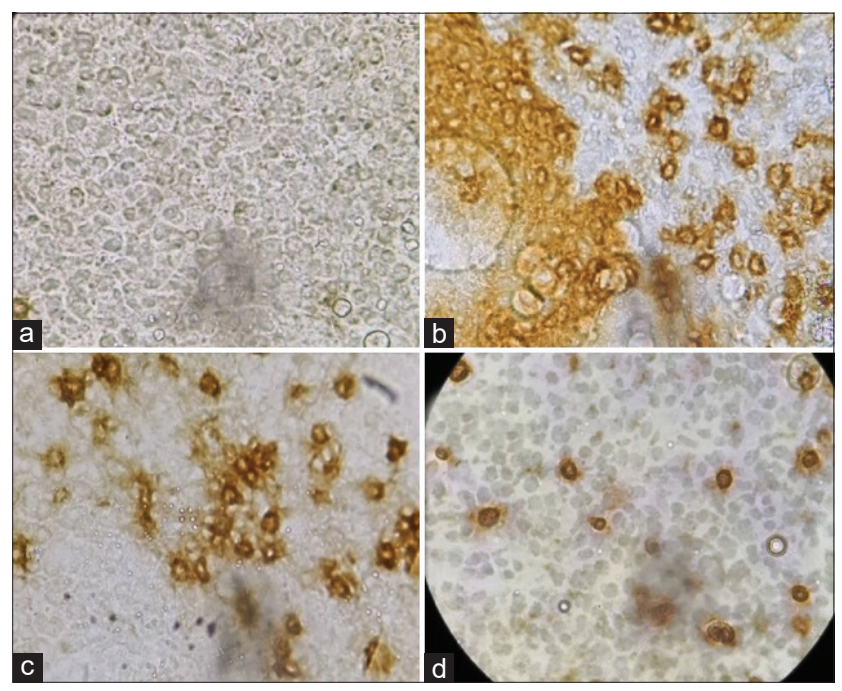

Figure-1: Thymus and bursa of Fabricius sections showing (a) isotype control. (b) Bursa of Fabricius cell showing lymphocytes expressing Bu-1 marker (brown in color). (c) Thymocytes expressing CD4 marker (brown-stained cells). (d) Thymocytes expressing CD8 marker (brownstained cells). Primary antibody and biotinylated horse anti-mouse IgG secondary antibody were the first to treat the section. A "charged" DAB (Abcam, USA) was the primary stain to develop color and methyl green was the counterstain.

scattered batches within the red and white bulbs of the spleen.

\section{Flow cytometry}

The data obtained showed that $\mathrm{T}$ lymphocytes (particularly those with the CD8 marker) were dominant in the spleen (Figure-3/spleen). Thymocytes showed that the CD3 marker was the denser marker expressed among all the cells in thymus. Moreover, 


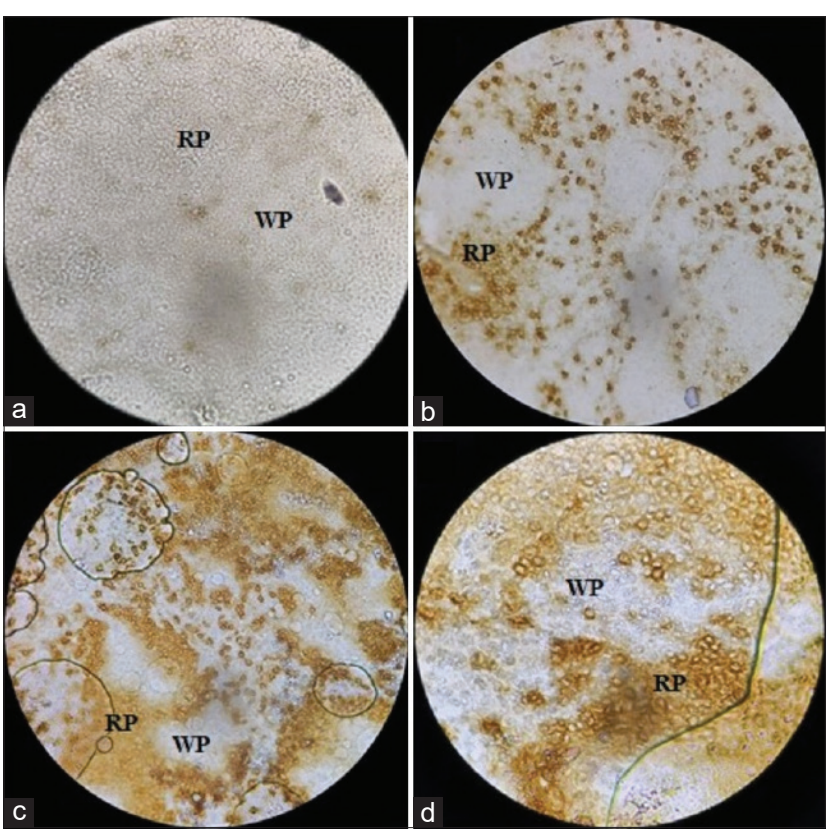

Figure-2: Spleen section showing: (a) Isotype control. (b) $\mathrm{CD} 8\left(\mathrm{CD}^{-} \mathrm{CD}^{+}\right)$lymphocyte stained in brown color especially in red bulb (RP) 40x. (c) Lymphocytes expressing CD3 marker 100x. (d) Lymphocytes expressing Bu-1 marker 100x. Primary antibody and biotinylated horse anti-mouse IgG secondary antibody were the first to treat the section. A "charged" DAB (Abcam, USA) was the primary stain to develop color and methyl green was the counterstain.

all the lymphocytes in the thymus expressed both $\mathrm{CD} 4$ and $\mathrm{CD} 8\left(\mathrm{CD} 4^{+} \mathrm{CD} 8^{+}\right)$with traces of $\mathrm{CD} 4$ $\mathrm{CD} 8{ }^{-}, \mathrm{CD}^{+}{ }^{+} \mathrm{CD} 8^{-}$, and $\mathrm{CD}^{-} \mathrm{CD}^{+}$(Figure-3/thymus). Conversely, the Bu-1 marker was highly expressed by the lymphocytes in the bursa (Figure-3/bursa). However, the vast majority of the lymphocyte population in the bursa was not expressing any marker (i.e. $\mathrm{CD}^{-} \mathrm{CD}^{-}$). Thus, various lymphocyte subpopulations were identified within each lymphoid organ using both flow cytometry and immunohistochemistry. These two procedures, i.e., flow cytometry and immunohistochemistry, have been applied to cell suspension obtained from the lymphoid organs (Table-3).

\section{Discussion}

Several attempts are being made to understand the immune cells and immune pathways in commercial chickens due to the economic importance of these breeds [7,23]. However, it is equally important to understand the immune regulation system in local breeds of chicken, particularly in developing countries. Indigenous breeds of chickens stand in an intermediate position between wild and commercial breeds [24].

Despite being cosmopolitan, rural or local breeds of chickens show significant refraction for most infections $[25,26]$. In the present study, we sought to determine the presence and density of the acquired immune system cells, that is, lymphocytes and their populations, in the primary and peripheral lymphoid organs. The lymphocyte viability was observed and the viable
Table-3: Determination of lymphocyte population subsets in lymphoid organs.

\begin{tabular}{|c|c|c|c|}
\hline Cell phenotype & $\begin{array}{c}\text { Thymus } \\
(\%)\end{array}$ & $\begin{array}{c}\text { Spleen } \\
(\%)\end{array}$ & $\begin{array}{c}\text { Bursa of } \\
\text { Fabricius } \\
(\%)\end{array}$ \\
\hline $\mathrm{CD}^{+}(\mathrm{T}-$ Cell $)$ & 4.4 & 62.3 & 2.04 \\
\hline $\mathrm{Bu}-1^{+}(\mathrm{B}-\mathrm{Cell})$ & 0.27 & 34.1 & 98.2 \\
\hline $\mathrm{CD}^{+}{ }^{+} \mathrm{CD} 8-(\mathrm{T}-$ helper$)$ & 0.36 & 16.2 & 0.39 \\
\hline CD4-CD8+ (Cytotoxic T-Cell) & 3.91 & 39.5 & 0.2 \\
\hline $\mathrm{CD}^{+}{ }^{+} \mathrm{CD} 8^{+}$ & 91 & 13.5 & 0.4 \\
\hline $\mathrm{CD} 4^{-\mathrm{CD}} 8^{-*}$ & 4.76 & 30.9 & 99 \\
\hline Total CD4 ${ }^{++}$ & 91.36 & 29.7 & 0.79 \\
\hline Total $\mathrm{CD}^{+*}$ & 94.91 & 53 & 0.6 \\
\hline Small mononuclear cells§ & 73.1 & 60.2 & 58.4 \\
\hline
\end{tabular}

Flow cytometry procedure has been applied for cell suspensions from thymus, bursa of Fabricius and spleen. Depending on the lymphocyte cell markers, the proportion of each cell was calculated in 8-week-old local breed male chickens $(n=30)$. *Very immature thymocytes, ${ }^{+}$includes $\mathrm{CD}^{+}{ }^{+} \mathrm{CD} 8{ }^{-}$and $\mathrm{CD}^{+}{ }^{+} \mathrm{CD} 8^{+}{ }^{+}{ }^{*}$ includes $\mathrm{CD} 4{ }^{-} \mathrm{CD} 8^{+}$and $\mathrm{CD} 4{ }^{+} \mathrm{CD} 8$

cells were counted within the lymphoid organs. The data showed similarity to those in genetically divergent breeds of chicken (Table-1). In addition, the weights and weight percentage of the primary and secondary lymphoid organs were within the normal range when compared to those of their commercial counterparts (light breeds in particular) (Table-2) [27]. Like other vertebrates, avian lymphocytes are distributed in the primary lymphoid organs; they migrate to the secondary lymphoid organs where they encounter the antigen. The lymphocytes are divided into $\mathrm{B}$ and $\mathrm{T}$ lymphocytes, based on their sites of origin and maturation [28]. In the present study, $\mathrm{T}$ and $\mathrm{B}$ lymphocytes were detected in the thymus with the balance shifted in favor of the T lymphocytes. Furthermore, $\mathrm{CD}^{+}$cells were dominant in the thymus and spleen (Figures-1 and 3 and Table-3). In the bursa of Fabricius, lymphocytes expressing the $\mathrm{Bu}-1$ marker were predominant (Figures-1 and 3). Around 98\% of the lymphocyte population in this primary lymphoid organ expressed the Bu-1 marker (Table-3). In the spleen, the proportion of the two cells was almost equally distributed with more cells expressing the $\mathrm{CD} 4{ }^{-} \mathrm{CD} 8^{+}$marker in the red pulp (Figure-2). This could be attributed to the main function of the spleen as a secondary immune organ. The $\mathrm{T}$ lymphocytes encounter their cognate antigen-presenting cells in the spleen. In addition, B lymphocytes have the tendency to relocate over the zones according to their activation status [29-31].

Analysis of the lymphocyte subpopulations in the thymus revealed that all the various markers (CD4 ${ }^{-} \mathrm{CD} 8^{-}, \mathrm{CD}^{+}{ }^{+} \mathrm{CD} 8^{-}, \mathrm{CD}^{-} \mathrm{CD}^{+}$, and $\mathrm{CD}^{+}{ }^{+} \mathrm{CD} 8^{+}$) were expressed by the cells. However, the proportion of each cell type was different (Figure-3). Thymocytes with $\mathrm{CD}^{+}{ }^{+} \mathrm{CD} 8^{-}$markers were predominant, whereas the marker $\mathrm{CD} 4^{+} \mathrm{CD} 8^{+}$was the least marker expressed by these cells. This is consistent with the findings of Bucy et al. [30]. The $\mathrm{CD}^{-} \mathrm{CD} 8^{-}$marker was highly expressed in the bursa (Figures-1 and 3). On the other 


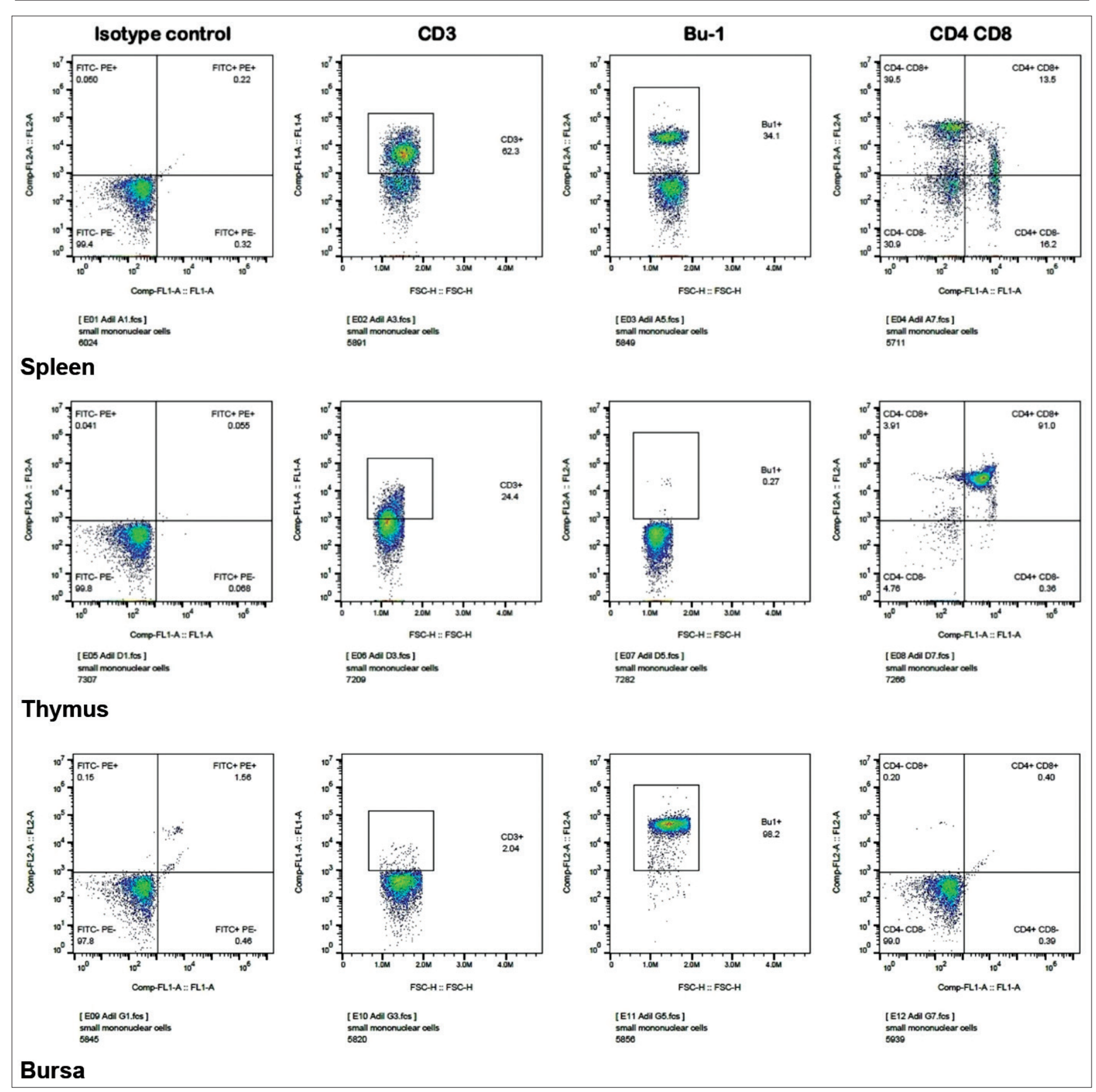

Figure-3: Flow cytometry results of cell suspension from spleen, thymus, and bursa of Fabricius. T lymphocytes (CD8 in particular with $\mathrm{CD}^{-} \mathrm{CD}^{+}$marker) were the dominant cells in the spleen. Thymocytes show that the CD3 marker is denser than that in bursa. Conversely, the Bu-1 marker is highly expressed by the lymphocytes in bursa. All the lymphocytes in the thymus were expressing both $\mathrm{CD} 4$ and $\mathrm{CD} 8$ markers $\left(\mathrm{CD} 4^{+} \mathrm{CD} 8^{+}\right)$with traces of $\mathrm{CD} 4^{-} \mathrm{CD} 8^{-}, \mathrm{CD}^{+} \mathrm{CD} 8^{-}, \mathrm{and}^{-} \mathrm{CD} 4^{-} \mathrm{CD} 8^{+}$. In the bursa, almost all the lymphocytes are expressing no marker $\left(\mathrm{CD} 4^{-} \mathrm{CD} 8^{+}\right)$.

hand, the spleen, which is a secondary lymphoid organ, harbored dense populations of both $\mathrm{T}$ and $\mathrm{B}$ lymphocytes, with a relative dominance of $\mathrm{T}$ lymphocyte (particularly the CD8 type of cells), which might be attributed to the fact that the CD8 cytotoxic $\mathrm{T}$ cells encounter the endogenous antigens (Figure-3 and Table-3) [27,32]. However, these proportions are changeable due to several factors, including the presence of an infection.

\section{Conclusion}

Our results showed that despite genetic divergence, local breeds of chicken could serve as a good and reliable model for studying the immune system of commercial breeds of chicken due to similarities in the presence and distribution of the immune cells $[33,34]$. No significant variations in the presence of these immune cells and their distribution within the primary or secondary immune organs have been recorded when compared to their commercial counterparts (commercial light breeds in particular) [35]. Therefore, there is no detectable immune variability in favor of the local breed when confronted by infections. The natural relative resistance of these breeds could be attributed to hygiene practices. Therefore, these birds might have undergone long-term natural selection [36]. 


\section{Authors' Contributions}

ASA and SSH: Conceived and designed the experiment, conducted and analyzed the data, and contributed to the manuscript drafting and revisions. Both authors read and approved the final manuscript.

\section{Acknowledgments}

We thank Dr. Ali Mahdi Mutlag, Assistant Professor at College of Science, University of Wasit for his assistance in imaging the slides. This work is ostensibly funded by the Iraqi Ministry of Higher Education and Scientific Research.

\section{Competing Interests} interests.

The authors declare that they have no competing

\section{Publisher's Note}

Veterinary World remains neutral with regard to jurisdictional claims in published institutional affiliation.

\section{References}

1. Litman, G.W., Rast, J.P. and Fugmann, S.D. (2010) The origins of the adaptive immunity. Nat. Rev. Immunol., 10(8): 543-553.

2. Júnior, A.F., dos Santos, J.P., Sousa, I.O., Martin, I., Alves, E.G.L. and Rosado, I.R. (2018) Gallus gallus domesticus: Immune system and its potential for generation of immunobiologics. Ciência Rural, 48(8): e20180250.

3. Fair, J.M., Taylor-McCabe, K.J., Shou, Y. and Marrone, B.L. (2008) Immunophenotyping of chicken peripheral blood lymphocyte subpopulations: Individual variability and repeatability. Vet. Immunol. Immunopathol., 125(3-4): 268-273.

4. De Boever, S., Croubels, S., Demeyere, K., Lambrecht, B., De Backer, P. and Meyer, E. (2010) Flow cytometric differentiation of avian leukocytes and analysis of their intracellular cytokine expression. Avian Pathol., 39(1): 41-46.

5. Weber, W.T. (2000) In vitro characterization of chB6 positive and negative cells from early avian embryos. Cell. Immunol., 204(2): 77-87.

6. Igyarto, B.Z., Nagy, N., Magyar, A. and Olah, I. (2008) Identification of the avian B-cell-specific Bu-1 alloantigen by a novel monoclonal antibody. Poult. Sci., 87(2): 351-355.

7. Bridle, B.W., Julian, R., Shewen, P.E., Vaillancourt, J. and Kaushik, A.K. (2006) T lymphocyte subpopulations in commercially raised chickens. Can. J. Vet. Res., 70(3): 183-190.

8. Lee, I.K., Gu, M.J., Ko, K.H., Bae, S., Kim, G., Jin, G., Kim, E.B., Kong, Y., Park, T.S., Park, B., Jung, H.J., Han, S.H. and Yun, C. (2018) Regulation of $\mathrm{CD}^{+} \mathrm{CD}^{-}$ $\mathrm{CD} 25^{+}$and $\mathrm{CD} 4^{+} \mathrm{CD} 8^{+} \mathrm{CD} 25^{+} \mathrm{T}$ cells by gut microbiota in chicken. Sci. Rep., 8(1): 8627.

9. Chen, C.H., Göbel, T.W.F., Kubota, T. and Cooper, M.D. (1994) T cell development in the chicken. Poult. Sci., 73(7): 1012-1018.

10. Sekelova, Z., Polansky, O., Stepanova, H., Fedr, R., Faldynova, M., Rychlik, I. and Vlasatikova, L. (2017) Different roles of CD4, CD8 and $\gamma \delta$ T-lymphocytes in naive and vaccinated chickens during Salmonella enteritidis infection. Proteomics. 17(13-14): 73.

11. Williamson, S.L.H., Steward, M., Milton, I., Parr, A., Piggott, N.H., Krajewski, A.S., Angus, B. and Horne, C.H.W. (1998) New monoclonal antibodies to the T cell antigens Cd4 and CD8. Am. J. Pathol., 152(6): 1421-1426.

12. Msoffe, P.L.M., Mtambo, M. M. A., Minga, U.M., Gwakisa, P.S., Mdegela, R.H., and Olsen, J.E. (2002).
Productivity and natural disease resistance potential of free-ranging local chicken ecotypes in Tanzania. Livest. Res. Rural Dev. 14(3). http://www.cipav.org.co/lrrd/ lrrd14/3/msof143.htm. [Last accessed on $2021 \mathrm{Jul} 18$ ].

13. M'Sadeq, S.A., Wu, S., Choct, M. and Swick, R.A. (2018) Influence of trace mineral sources on broiler performance, lymphoid organ weights, apparent digestibility, and bone mineralization. Poult. Sci., 97(9): 3176-3182.

14. Bewrger, C.L. and Edelson, R.L. (1979) Comparison of lymphocyte functions after isolation by Ficoll-hypaque floatation and elutriation. J. Invest. Dermatol., 73(3): 231-235.

15. Wu, Y., Lu, H., Cai, J., He, X., Hu, Y., Zhao, H. and Wang, X. (2009), Membrane surface nanostructures and adhesion property of T lymphocytes exploited by AFM. Nanoscale Res. Lett., 4(8): 942-947.

16. Jergović, M., Nedeljković, G., Cvetić, Ž., Gottstein, Ž. and Bendelja, K. (2017) Combined dextran and ficoll separation yields pure populations of chicken peripheral blood mononuclear cells-short communication. Vet. Arhiv., 87(5): 623-630.

17. Mansour, I., Bourin, P., Rouger, P. and Doinel, C. (1990) A rapid technique for lymphocyte preparation prior to twocolor immunofluorescence analysis of lymphocyte subsets using flow cytometry comparison with density gradient separation. J. Immunol. Methods, 127(1): 61-71.

18. Rimondi1, A., Pinto, S., Oliver, V., Dibárbora, M., Pérez-Filgueira, M., Craig, M.I. and Pereda, A. (2014) Comparative and histopathological and immunological study of two field strains of chicken anemia virus. Vet. Res., 45(1): 102

19. Ko, K.H., Lee, I.K., Kim, G., Gu, M.J., Kim, H.Y., Park, B.C., Park, T.S., Han, S.H. and Yun, C. (2018) Changes in bursal B cells in chicken during embryonic development and early life after hatching. Sci. Rep., 8(1): 16905.

20. Dulwich, K.L., Asfor, A.S., Gray, A.G., Nair, V. and Broadbent, A.J. (2018) An ex vivo chicken primary bursal-cell culture model to study infectious bursal disease virus pathogenesis. J. Vis. Exp., 140: e58489.

21. Pertile, T.L., Walser, M.M., Sharma, J.M. and Shivers, J.L. (1996) Immunohistochemical detection of lymphocyte subpopulations in the tarsal joints of chicken with experimental viral arthritis. Vet. Pathol., 33(3): 303-310.

22. Zhang, Q., Waqas, Y., Yang, P., Sun, X., Liu, Y., Ahmed, N., Chen, B., Li, Q., Hu, L., Huang, Y., Chen, H., Hu, B. and Chen, Q. (2017) Cytological study on the regulation of lymphocyte homing in the chicken spleen during LPS stimulation. Oncotarget, 8(5): 4705-4715.

23. Noujaim, J.C., Filho, R.L.A., Lima, E.T. and Okamoto, A.S. (2009) Detection of CD4+ and CD8+ lymphocytes in the intestine of broiler chicks treated with Lactobacillus spp. and challenged with Salmonella enterica serovar Enteritidis. Brazi. J. Poul. Sci., 11(3): 154-160.

24. Hata, A., Nunome, M., Suwanasopee, T., Duengkae, P., Chaiwatana, S., Chamchumroon, W., Suzuki, T., Koonawootrittriron, S., Matsuda, Y. and Srikulnath, K. (2021) Origin and evolutionary history of domestic chickens inferred from a large population study of Thai red junglefowl and indigenous chickens. Sci. Rep., 11(1): 2035.

25. Ikpeme, E.V., Ekerette, E.E., Efienokwu, J.N. and Ozoje, M.O. (2019) Immune response of Nigerian chicken genotypes to salmonella and Newcastle vaccines. Trends Appl. Sci. Res., 14(4): 296-302.

26. Haunshi, S. and Rajkumar, U. (2020) Native chicken production in India: Present status and challenges. Livest. Res. Rural Dev., 32(11): 181.

27. Hofman, T. and Schmuker, S. (2021) Characterization of chicken leukocyte subsets from lymphatic tissue by flow cytometry. J. Quant. Cell Sci., 99(3): 289-300.

28. Birhan, M. (2019) Systemic review on avian immune systems. J. Life Sci. Biomed., 9(5): 144-150. 
29. Bucy, R.P., Chen, C.L., Cihak, J., Lösch, U. and Cooper, M.D. (1988) Avian T cells expressing gamma delta receptors localize in the splenic sinusoids and the intestinal epithelium. J. Immunol., 141(7): 2200-2205.

30. Bucy, R.P., Chen, C.L. and Cooper, M.D. (1990) Ontogeny of $\mathrm{T}$ cell receptors in the chicken thymus. J. Immunol., 144(4): 1161-1168.

31. Lewis, S.M., Williams, A. and Eisenbarth, S.C. (2019) Structure-function of the immune system in the spleen. Sci. Immunol., 4(33): 6085.

32. Jeurissen, S.H., Janse, E.M. Ekino, S., Nieuwenhuis, P., Koch, G. and de Boer, G.F. (1988) Monoclonal antibodies as probes for defining cellular subsets in the bone marrow, thymus, bursa of Fabricius, and spleen of the chicken. Vet. Immunol. Immunopathol., 19(3-4): 225-238.

33. Hammer, D.K. (1974) The immune system in chickens. Avian Pathol., 3(2): 65-78.
34. Mpenda, F.N., Schilling, M.A., Campbell, Z., Mngumi, E.B. and Buz, J. (2019) The genetic diversity of local African chickens: A potential for selection of chickens resistant to viral infections. J. Appl. Poult. Res., 28(1): 1-12.

35. Psifidi, A., Banos, G., Matika, O., Desta, T.T., Bettridge, J., Hume, D.A., Dessie, T., Christley, R., Wigley, P., Hanotte, O. and Kaiser, P. (2016) Genome-wide association studies of immune, disease and production traits in indigenous chicken ecotypes. Genet. Sel. Evol., 48(1): 74.

36. Banos, G., Lindsay, V., Desta, T.T., Bettridge, J., SanchezMolano, E., Vallejo-Trujillo, A., Matika, O., Dessie, T., Wigley, P., Christley, R.M., Kaiser, P., Hanotte, O. and Psifidi, A. (2020) Integrating genetic and genomic analyses of combined health data across ecotypes to improve disease resistance in indigenous African chickens. Front. Genet., 11: 543890 .

$* * * * * * * *$ 